\title{
Alternatif Fermentasi Bio-Etanol dari Bagas Tebu oleh Zymomonas mobilis
}

\section{Bio-Ethanol Fermentation Alternative of Sugarcane Bagasse by Zymomonas mobilis}

\author{
In-In Hanidah ${ }^{1}$, Ratu Safitri ${ }^{2}$, Toto Subroto ${ }^{2}$ \\ ${ }^{1}$ Dosen FTIP, Universitas Padjadjaran \\ ${ }^{2}$ Dosen FMIPA, Universitas Padjadjaran \\ J1. Raya Bandung - Sumedang KM.21, Jatinangor, Indonesia \\ Email Korespondensi : inin@unpad.ac.id; pinkyhanidah@yahoo.com
}

\begin{tabular}{l} 
A R T I C L E IN F O \\
\hline Article history \\
Received: 13 Juni 2016 \\
Accepted: 21 Juli 2016 \\
Available online: Februari 2017 \\
\hline Keywords: \\
Zymomonas mobilis \\
bio-ethanol \\
sugarcane bagasse.
\end{tabular}

Kata kunci :

Zymomonas mobilis

bio-etanol

Bagas tebu.

\begin{abstract}
A B STRACT
Sugarcane bagasse (Saccharum officinarum, $L$ ) is a readily available waste product of cane-sugar processing which is a potential source of biomass for the production of bio-ethanol. Bagasse contains a lot of cellulose, hemicellulose, and lignin bit. Treatment with sulphuric acid hydrolysis or alkaline only able to describe bonding cellulose and hemicellulose from the lignin. Zymomonas mobilis capable of producing ethanol with high productivity of the types of carbohydrates glucose, fructose, and sucrose than Saccharomyces cerevisiae. The purpose of research is to determine the concentration of ethanol derived from sugarcane bagasse hydrolyzate fermentation by Z. mobilis FNCC 0056. The experiment employed descriptive analyses in triplicates and 12-hour fermentation period. The results showed, Effectiveness of Z. mobilis 0056 FNCC was highest for producing bio-ethanol, $18,99 \mathrm{~g} / \mathrm{L}$ within 3 hours.
\end{abstract}

\section{A B S T R A K}

Bagas tebu (Saccharum officinarum, L) adalah limbah produksi dari gula tebu yang merupakan sumber biomasa potensial untuk produksi bio-etanol. Bagas mengandung banyak selulosa, hemiselulosa, dan sedikit lignin. Perlakuan hidrolisis dengan larutan asam maupun basa hanya mampu menguraikan ikatan selulosa dan hemiselulosa dari lignin. Zymomonas mobilis mampu menghasilkan etanol dengan produktivitas tinggi dari jenis karbohidrat glukosa, fruktosa, dan sukrosa dibandingkan Saccharomyces cerevisiae. Tujuan penelitian adalah untuk mengetahui kadar etanol yang diperoleh dari fermentasi hidrolisat bagas tebu oleh Z. mobilis FNCC 0056. Metode penelitian yang dilakukan adalah metode deskriptif dengan 3 kali ulangan dan waktu fermentasi 12 jam. Hasil penelitian menunjukkan, Z. mobilis FNCC 0056 mampu menghasilkan bio-etanol tertinggi sebesar 18,99 g/L dengan waktu fermentasi 3 jam.

\section{Pendahuluan}

Bagas tebu (Saccharum officinarum, L) merupakan sumber biomasa potensial untuk produksi bio-etanol. Bagas mengandung banyak selulosa dan sedikit lignin, selain itu bagas tebu adalah limbah pabrik gula sehingga murah dan selalu tersedia. Bagas tebu adalah padatan sisa dari proses ekstraksi cairan tebu. Saat ini bagas tebu hanya digunakan untuk memproduksi uap dan listrik dalam sistem pengolahan tebu. Untuk kebutuhan tersebut, secara tradisionalbagas tebu dibakar dengan tujuan menghasilkan energi dan mengurangi masalah limbah (Samsuri et al., 2006).

Produksi etanol dari bahan selulosa secara prinsip mula-mula dilakukan proses pra-perlakuan diantaranya dengan pengecilan ukuran danpemanasanuap,kemudian dilanjutkan hidrolisis secara kimia seperti menggunakanasam sulfat atau natrium hidroksida, selanjutnya dilakukan hidrolisis enzimatik. Proses hidrolisis bertujuan menguraikan berbagai komponen utama bahan berlignoselulosa yaitu polimer selulosa, hemiselulosa, lignin, bahan ekstraktif, dan abu. Selanjutnya menguraikan polimer polisakarida menjadi monomer-monomer gula heksosa dan pentosa (gula tunggal) yang dapat difermentasi menjadi etanol (Demirbas, 2005).

Z. mobilis merupakan bakteri gram negatif, berbentuk batang (basil), dapat ditemukan pada tanaman getah yang kaya akan gula, memiliki ukuran panjang 2 $6 \mu \mathrm{m}$ dan lebar $1-1,4 \mu \mathrm{m}$, suhu optimum untuk pertumbuhannya $25-30^{\circ} \mathrm{C}$, anaerobik, dapat diisolasi dari gula tebu atau minuman alkohol lain seperti wine palm, cider, dan bir (Anonim, 2002). 
Z. mobilis dapat memfermentasi glukosa, fruktosa, tetapi tidak dapat memfermentasi silosa.(Gunasekaran et al., 2005; Rouholah et al., 2007; Gurav\&Geeta., 2007). Namun, Z. mobilis mampu menghasilkan etanol dengan produktivitas tinggi dari jenis karbohidrat glukosa, fruktosa, dan sukrosa melalui lintasan Entner Duodoroff(Obire, 2005; Tripetchekul et al., 1998) dengan produksi biomassa lebih rendah, dan tidak memerlukan kontrol oksigen selama proses fermentasi. Tetapi $Z$. mobilis FNCC 0056 menghasilkan produk sampingan seperti sorbitol, aseton, gliserol dan asam asetat serta formasi ekastraseluler polimer levan (Gunasekaran dan Raj, 2005).

Menurut Gunasekaran dan Raj (2005), fermentasi dengan $Z$. mobilis memiliki beberapa kelebihan dibandingkan $S$. cereviciae, yaitu: dalam proses fermentasi Z. mobilis melalui lintasan Entner-Doudroff yang menghasilkan 1 ATP dari setiap 1 molekul glukosa dan biomassa yang rendah, sehingga produksi etanol yang dihasilkan lebih banyak, Z. mobilis mampu menghasilkan 9 mol etanol untuk setiap 1 molekul glukosa. Jumlah ini lebih besar dibandingkan hasil dari Saccharomyces yang hanya menghasilkan 2 molekul etanol untuk setiap 2 molekul glukosa, dan Z. mobilis memiliki sifat lebih toleran terhadap etanol dengan konsentrasi 2,5 - 15\% karena memiliki struktur membran plasma yang mengandung senyawa hopanoid dan sterol.

Keunggulan lain yang dimilikiZ. mobilis antara lain: merupakan mikroorganisme fermentasi alami (GRAS), secara teoritis menghasilkan etanol dari glukosa, tidak memerlukan oksigen untuk pertumbuhan, lebih toleran terhadap senyawa inhibitor dalam hidrolisat, toleran terhadap kadar etanol tinggi, fermentasi pada $\mathrm{pH}$ rendah, tumbuh pada konsentrasi gula tinggi, dan produksi tinggi (Kompala et al., 2001).

Tujuan penelitian adalah untuk mengetahui kadar etanol yang diperoleh dari fermentasi hidrolisat bagas tebu oleh Z. mobilis FNCC 0056.

\section{Metode Penelitian}

Bahan utama yang digunakan dalam penelitian ini antara lain: bagas tebu (Saccharum officinarum) yang berasal dari perkebunan Persada Batu PT. RNI (Rajawali Nusantara Indonesia) berlokasi di Cirebon dan strain $Z$. mobilis FNCC 0056 dari koleksi kultur biakan Laboratorium Mikrobiologi Universitas Gadjah Mada.

Media starter untuk kulturZ. mobilis FNCC 0056 digunakan YEPD / Zymomonas medium broth yang per liter mengandung: $10 \mathrm{~g}$ yeast extract, $10 \mathrm{~g}$ peptone, $20 \mathrm{~g}$ glukosa, dan $1 \mathrm{~L}$ aquades. Mediaum agar dengan penambahan $15 \mathrm{~g}$ agar-agar/L (Atlas, 1993). Kulturditumbuhkan pada media adaptasi dengan cara mengambil 3\% suspensi kultur murni (setara McFarland 3) kedalam erlenmeyer $250 \mathrm{ml}$ yang berisi $100 \mathrm{ml}$ media adaptasi (YEPD broth/Zymomonas medium), inkubasi secara aerobik pada suhu $30^{\circ} \mathrm{C}$ dengan menggunakan shaker. Waktuinkubasi untuk Z. mobilis FNCC 0056 selama 12 jam.
Hidrolisat ditambah medium pengaya fermentasi yang mengandung (/L): $4 \mathrm{~g}$ yeast extract, $2 \mathrm{~g} \mathrm{KH}_{2} \mathrm{PO}_{4}, 3 \mathrm{~g}$ $\left(\mathrm{NH}_{4}\right)_{2} \mathrm{SO}_{4}, 1 \mathrm{~g} \mathrm{MgSO}{ }_{4} \cdot 7 \mathrm{H}_{2} \mathrm{O}$, dan 3,6 g pepton (Sanchez et al., 2002). Kemudian, dilakukan pengaturan $\mathrm{pH}$ sampai 7, selanjutnya disterilisasi dalam autoclave pada suhu $121^{\circ} \mathrm{C}$ selama 15 menit.

Penambahan inokulum bakteri Z. mobilis FNCC pada penelitian ini adalah $10 \%(\mathrm{v} / \mathrm{v})$. Inokulum $Z$. mobilis FNCC dimasukkan ke dalam erlenmeyer $100 \mathrm{ml}$ yang berisi substrat fermentasi sebanyak $30 \mathrm{ml}$. Kemudian diinkubasi pada suhu $30^{\circ} \mathrm{C}$, selama 21 jam, $\mathrm{pH} 7$, dan kecepatan agitasi $100 \mathrm{rpm}$. Setiap 3 jam dilakukan pengukuran $\mathrm{pH}$, jumlah sel (cfu), kadar etanol, dan gula reduksi.

Perhitungan pertumbuhan mikroorganisme dilakukan dengan metode turbidimetri. Jumlah mikroba yang hidup diasumsikan dengan tingkat kekeruhan yang diukur dengan spektrofotometer pada $\lambda 600 \mathrm{~nm}$ berdasarkan nilai absorbansi yang dikonversikan ke dalam jumlah sel hidup $(\mathrm{CFU} / \mathrm{ml})$ sesuai persamaan regresi linier

\section{Hasil dan Pembahasan}

Pada penelitian ini, Z. mobilis FNCC 0056mampu memanfaatkan nutrisi yang terdapat pada gula pereduksi hidrolisat tebu. Hal ini terlihat dari pertumbuhan yang sangat signifikan pada jam ke-6 mampu tumbuh 2 kali lipat dari jumlah sel awal (Gambar 1).

Fase ini merupakan fase log atau ekponensial yaitu terjadi perbanyakan, multiplikasi berjalan lancar, dan pembelahan sel yang jumlahnya sama dengan persamaan eksponensial. Semua nutrien yang dibutuhkan tersedia, sehingga pertumbuhan rata-rata ditentukan oleh komposisi medium dan faktor-faktor lingkungan. Pada fase ini terjadi kegiatan fisiologi sel yang menyebabkan terbentuknya senyawa-senyawa seperti: etanol, asam lemak, asam organik, dan lain-lain.

Berdasarkan hasil penelitian yang disajikan pada Gambar 1, fase adaptasiterjadi sampai jam ke-3 fermentasi. Fase adaptasi merupakan fase penyesuaian terhadap lingkungan baru, terjadi sintesis enzim baru yang sesuai dengan media. Pada fase ini jumlah sel tidak meningkat tetapi volume sel bertambah. Hal ini menunjukkan bahwa Z. mobilis FNCC 0056mampu memanfaatkan hidrolisat bagas tebu sebagai sumber nutrisi pertumbuhannya. Berdasarkan hasil analisis HPLC hidrolisat tebu yang digunakan untuk proses fermentasi mengandung $23,78 \%$ glukosa, $56,91 \%$ silosa, dan $19,31 \%$ arabinosa.

Pengukuran jumlah sel mikroorganisme selama proses fermentasi berlangsung berdasarkan konversi nilai absorbansi, maka fase late log (pertumbuhan lambat) dapat diketahui adanya pertambahan sel yang agak lambat setelah fase log yang terjadi mulai jam ke-12 fermentasi.

Fase late log merupakan fase pertumbuhan mikroorganisme diperlambat karena zat nutrisi di dalam medium sudah berkurang dan adanya hasil-hasil metabolisme yang mungkin beracun atau dapat menghambat perumbuhan mikroorganisme. Pada fase ini, 
pertumbuhan sel tidak stabil, tetapi jumlah populasi masih naik karena jumlah sel yang tumbuh masih lebih banyak dari pada sel mati (Sukarminah dkk, 2008). Dengan demikian, dapat diketahui laju pertumbuhan spesifik maksimal $\left(\mu_{\max }\right)$ dariZ. mobilis FNCC 0056 sebesar 0,90 $\mathrm{CFU} /$ jam. Semakin tinggi nilai $\mu_{\max }$ maka semakin tinggi kecepatan pertumbuhan biomasa yang menandakan konsentrasi makromolekul meningkat, tetapi RNA relatif lebih banyak dibanding dengan makromolekul lain, karena terjadi peningkatan jumlah ribosom. Menurut Silalahi (1987), Z. mobilis FNCC 0056 memiliki waktu pertumbuhan yang lebih cepat, $3-4$ kali lebih cepat dibandingkan ragi.

Pertumbuhan cepat Z. mobilis FNCC 0056 sejalan dengan etanol yang terbentuk (Gambar 1). Secara teoritis Z. mobilis FNCC 0056 mampu menghasilkan etanol dengan produktivitas tinggi dari jenis karbohidrat glukosa, fruktosa, dan sukrosa (Obire, 2005; Tripetchekul et al., 1998)

Kadar gula pereduksi awal yang digunakan pada tahap fermentasi adalah 32,00 $\mathrm{g} / \mathrm{L}$ atau sebesar 3,20\% yang terdiri dari glukosa $(23,78 \%)$, silosa $(56,91 \%)$, dan arabinosa $(19,31 \%)$. Hasil akhir fermentasi mengandung gula pereduksi sebesar 11,39 $\mathrm{g} / \mathrm{L}$ dengan kemampuan mengkonsumsi $100 \%$ glukosa, $69,02 \%$ silosa, dan $45,96 \%$ arabinosa yang terdapat pada hidrolisat tebu hasil hidrolisis kombinasi asam-enzim tanpa detoksifikasi. Penelitian ini membuktikan, bahwa Z. mobilis FNCC 0056 tidak hanya mampu memfermentasi glukosa, tetapi juga mampu memfermentasi silosa dan arabinosa walaupun kemampuan memfermentasi gula C-5 (silosa dan arabinosa) tidak tinggi.

Menurut Yang et al. (2009), Z. mobilis FNCC 0056 secara efisien mampu memfermentasi glukosa, fruktosa, sukrosa menghasilkan etanol dan karbondioksida melalui lintasan Enter-Doudoroff dengan memanfaatkan enzim piruvat dekarboxilase dan alkohol dehidrogenase.

Kadar etanol yang dihasilkan sejalan dengan pertumbuhan kultur dan jumlah gula pereduksi yang dikonsumsi. Etanol yang terbentuk pada jam ke-3 fermentasi sebesar 18,99 $\mathrm{g} / \mathrm{L}$ kemudian terjadi penurunan dengan bertambahnya waktu fermentasi (Gambar 1). Hal ini menunjukkan bahwa produksi bioetanol dari hidrolisat bagas tebu dengan menggunakan Z. mobilis FNCC 0056 cukup efektif dan efisien karena memiliki waktu fermentasi singkat yaitu selama 3 jam.

Kecepatan proses fermentasi dimungkinkan karena konversi glukosa ke dalam dua molekul etanol dihasilkan 1 molekul ATP. Rendahnya energi ATP yang dihasilkan mengakibatkan massa sel yang dihasilkan rendah dan tingginya etanol yang dihasilkan (Jeffries, 2005).

Etanol yang terbentuk diiringi dengan penurunan $\mathrm{pH}$ karena pembentukan asam-asam organik ( $\mathrm{pH}$ akhir 5,12). Asam-asam organik yang terbentuk seperti asam asetat, asam piruvat dan asam laktat dapat menurunkan nilai $\mathrm{pH}$, sedangkan asam-asam lainnya seperti asam butirat dan asam lemak lainnya hanya sedikit berpengaruh dalam penurunan $\mathrm{pH}$ substrat (Wang et al, 1979).

Kecenderungan perubahan $\mathrm{pH}$ pada media fermentasi disebabkan amonia yang digunakan sel khamir sebagai sumber nitrogen diubah menjadi $\mathrm{NH}_{4}{ }^{+}$. Molekul $\mathrm{NH}_{4}{ }^{+}$akan menggabungkan diri ke dalam sel sebagai $\mathrm{R}$ $\mathrm{NH}_{3}$. Dalam proses ini $\mathrm{H}^{+}$ditinggalkan dalam media, sehingga semakin banyak biomassa dan bertambahnya waktu fermentasi menyebabkan ion $\mathrm{H}^{+}$ini semakin banyak dalam substrat yang menyebabkan $\mathrm{pH}$ media semakin rendah (Judoamidjojo \& Sa'id, 1993; Fardiaz, 1988).

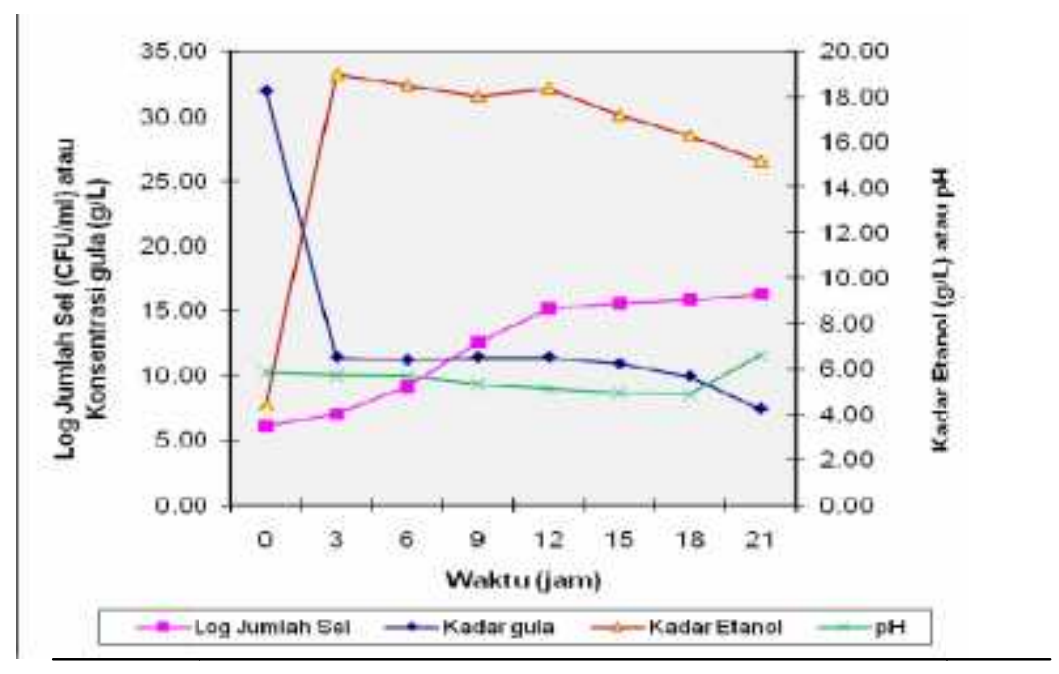

Gambar 1.Hubungan Pertumbuhan Z. mobilis FNCC 0056 dengan konsumsi gula pereduksi, produksi etanol, $\mathrm{pH}$ dari Hidrolisat Bagas Tebu 


\section{KESIMPULAN}

1. Z. mobilis FNCC 0056 mampu memfermentasi gula hidrolisat bagas tebu menjadi etanol sebesar 18,99 $\mathrm{g} / \mathrm{L}$ dengan waktu fermentasi 3 jam.

2. Z. mobilis FNCC 0056 memiliki kemampuan mengkonsumsi $100 \%$ glukosa, $69,02 \%$ silosa, dan $45,96 \%$ arabinosa yang terdapat pada hidrolisat tebu.

3. Etanol yang terbentuk diiringi dengan penurunan $\mathrm{pH}$ karena pembentukan asam-asam organik $(\mathrm{pH}$ akhir $5,12)$

\section{UCAPAN TERIMAKASIH}

Ucapan terimakasih dan penghargaan yang tak terhingga disampaikan kepada:

1. Deptan melalui Program KKP3T, atas bantuan dana penelitian yang diberikan selama penelitian.

2. Prodi Teknologi Pangan - FTIP UNPAD, atas fasilitas laboratorium yang diberikan untuk kelancaran penelitian.

\section{PUSTAKA}

Anonim.2002. Zymomonas mobilis. Didapat Tanggal 27 Maret 2009. Dari: http://microbewiki.kenyon.edu/index.php/Zymomo nas_mobilis.

Atlas, Ronald M. 1993. Handbook of Microbiological Media. CRC Press Boca Rotan Ann Arbor London. Tokyo.

Demirbas, A. 2005. Bioetanol from Cellulosic Materials : A Renewable Motor Fuel From Biomass. Energy Resources, 27: 327-337.

Fardiaz, S. 1988. Fisiologi Fermentasi. Pusat Antar Universitas Insitut Pertanian Bogor bekerjasama dengan Lembaga Sumberdaya Informasi-IPB.

Gunasekaran, P.T. \& K.C. Raj. 2005. Ethanol Fermentation Technology-Zymomonas mobilis. Department of Microbial Technology. School of Biological Sciences. Madurai Kamaraj University. India.

Gurav, M.S.,\&G.S.Geeta. 2007. Effectivenes of Fungal Pretreatment of Agro Residues on Etanol Production by Yeast and Zymomonas mobilis. Karnataka J. Agric.Sci, 20(2) : 301-304.
Jeffries, T.W. 2005. Ethanol Fermentation On The Move. Nature Biotechnology. 23(1) : 1-10.

Judoamidjojo, M., A. A. Darwis, \& E. G. Sa'id. 1992. Teknologi Fermentasi. Penerbit Rajawali. Jakarta.

Kompala, D.S. 2001. Maximizing Ethanol Production by Engineered Pentose-Fermenting Zymomonas mobilis. Department of Chemical Engineering University of Colorado. Boulder.

Obire, O. 2005. Activity of Zymomonas species in palmsap obtained from three areas in Edo State, Nigeria. J. Appl. Sci. Environ.9 : 25 - 30.

Samsuri, M., Misri, G., Heri, H., Bambang, P., M. Nasikin, \&T. Watanabe. 2006. Etanol Production From Bagasse With Combination Of CellulaseCellubiase In Simultaneous Saccharification And Fermentation (SSF) Using White Rot Fungi PreTreatment. Journal of Chemical and Natural Resources Eggineering, $3: 20-32$.

Silalahi, T. D.1987. Isolasi Bakteri Z. mobilis dari Nira Aren (Arenga pinnata) dan Menguji Kemampuannya dalam Pembuatan Alkohol dari Tetes. ITB. Bandung.

Sukarminah, E., Debby M.Sumanti., \& In-In Hanidah. 2008. Mikrobiologi Pangan. Buku Ajar Kulah Jurusan Teknologi Industri Pangan. FTIP. UNPAD. Jatinangor.

Tripetchkul, S., Z. D. Hilary, \& A. Ishizaki. 1998. Strategies for Improving Ethanol Production Using Zymomonas mobilis. Devel. in Agricultural \& Biological Chem. 2 : 41-55.

Wang, N.S 2009. Glucose Assay By Dinitrosalicylic Colorimetric Methods. Department of Chemical and Biomolecular Engineering. University of Maryland. Cpllege Park.

Yang, Shihui., Timothy J Tschaplinski, Nancy L Engle, Sue L Carroll, Stanton L Martin, \&Brian H Davison. 2009. Transcriptomic and metabolomic profiling of Zymomonas mobilis during aerobic and anaerobic fermentations. BMC Genomics doi (10.1186): 1471-2164-10-34. 